\title{
Sala de aula, pesquisa e aprendizagem
}

Paratore, J.R. \& McConnack, R.L. (1997). Peer talk in the classroom: 1earning from research. Newark: IRA, vii + 248p.

Espera-se que as inovações introduzi das em sala de aula sejam objeto de pesquisa que permitam a generalização e o uso posterior com segurança. Vale dizer que a sala de aula deve ser um laboratório para pesquisas educacionais e o que não estiver sendo alvo de pesquisa deve estar em uso em decorrência de pesquisas anteriores que lhe deram sustentação.

Embora este seja o quadro desejável, nem sempre é o que se encontra nas realidades de sala de aula, especialmente em países em que a pesquisa neste ambiente não é tradição e onde o professor-pesquisador é ainda uma quimera.

Um dos aspectos que tem merecido a atenção dos pesquisadores é o intercâmbio entre alunos no processo ensino-aprendizagem e a passagem do controle das atividades educacionais para o próprio aluno. As pesquisas na área apresentam estratégias para que isto ocorra de forma produtiva e o presente livro decorre de esforços de pesquisa neste setor.

Paratore atua na área de Educação na Boston University e McCormack é consultora sobre ensino de leitura e professora de escola pública em Plymouth, tendo organizado a obra com a colaboração de diversos professores pesquisadores.

O prefácio é assinado por Cazden, da Haward University, que destaca a crescente atenção dada ao assunto e alerta para o perigo de se sair do extremo de classe centrada no professor para o extremo de classe centrada no aluno que pode ser tão nefasto quanto o primeiro.

A Introdução é assinada pelas duas organizadoras que retomam Dewey, que, na virada do século (1900), afirmava que a escola não estava (e ainda não está) apta a aproveitar todos os instintos naturais dos estudantes (instintos: social, construtivo, investigativo e expressivo). A proposta é viabilizar melhorar o aproveitamento desta energia desperdiçada. Passam, então, a apresentar a organização do livro. Este está organizado em quatro palies, incluindo ainda índices de autores e de conteúdo além de autores de literatura infantil citados nos vários capítulos, o que facilita a tarefa do leitor mais curioso ou interessado em um tópico específico.

A Primeira Parte é composta por um único capítulo em que se procura fornecer um contexto teórico para a conversa dos alunos em classe recorrendo a enfoques diversos e à experiência prática. O capítulo é da autoria de Lapp, Flood, Ranck-Buhr, Van Dyke e Spacek e destaca os clubes do livro como estratégia básica e enriquecedora podendo ter abrangências diversas.

A Segunda Parte enfoca, diretamente, o aluno em sala de aula discutindo com seus colegas como forma de enriquecimento das oportunidades de aprendizagem. É constituída por cinco capítulos. No primeiro deles, McCormack descreve o comportamento de quatro alunos de segundo grau em interação e como constroem sua vivência tendo por referencial o construtivismo social. Apresenta o professor como pesquisador que explora a vivência do aluno e colhe evidências deste desenvolvimento dentro da experiência de grupo.

O Terceiro capítulo enfoca o aproveitamento da diversidade cultural freqüente em muitas classes (Kaser e Short). O ponto de partida é levar um aluno a conhecer o outro, via-entrevista, até a apresentação final das famílias. A ênfase está na recuperação da cultura da criança, o que tem implicações não apenas para a sala de aula, mas para a escola como um todo.

Boyd e Galda enfocam a interação verbal do prisma de lições aprendidas e ensinadas, o que pode melhorar a realização acadêmica, a retenção, o ensino especial e reduzir a evasão escolar. Discute a composição de grupos de crianças de idades diferentes e dá orientação para seminário de discussão. Além disso, apresenta comportamentos esperados de um bom tutor.

Kasten combate o velho e persistente mito de que a sala de aula precisa ser silenciosa para 
que ocorra a aprendizagem da leitura e da escrita. Retoma os círculos literários como meio de ensino.

Whitmore mostra que, também nas salas de aula, em que se aprende uma Segunda língua, é imprescindível a conversação entre os alunos. Cabe ao professor criar contexto para que ocorra a conversa. Propõe seminários com procedimentos específicos. Lembra a importância de colher e analisar os dados.

A Terceira Parte apresenta um exame dos conflitos e complexidades nas falas dos alunos e é composta por dois capítulos. O primeiro deles foi escrito por Almasi e Grambrele que procuram mostrar como usar bem os conflitos que ocorrem nas discussões feitas em classe; enfocam os papéis do conflito e descrevem o estudo dos vários tipos de conflito: consigo mesmo, com os outros e com o texto. Fornecem pistas de como podem ser resolvidos. No capítulo seguinte, Evans trata da questão de gênero no contexto destes conflitos e como tratá-la em sala de aula.

A palie final enfoca o docente no âmbito da discussão. Também é composta por dois capítulos. No nono Raphael, Brock e Wallace retomam o contexto de Vygotsky para situar a discussão tendo por base as relações privado (transformação) - público (convencionalismo) e individual (tomar público) - social (apropriação). Novamente os clubes de livro aparecem como instrumento para a conversação.

O último capítulo trata de trabalho de observação de professores que observam crianças falarem de livros. Foi elaborado por Paratore, Garnick e Lewis. Formas de registro são propostas e a literatura infantil é usada como texto, mas o foco da atenção é o docente em ação.

Os capítulos apresentam bibliografia recente e pertinente e, ao término de todos, o leitor encontra as conclusões relativas ao mesmo e algumas questões para serem objeto de consideração.

Falta um capítulo de síntese e que funcione como fecho do apresentado anteriormente, incluindo uma análise crítica do produzido e do relatado. Há quase total ausência de apresentação de limitações e críticas ao exposto, como tônica em todos os capítulos.

Para os que trabalham com leitura, quer como docentes, quer como pesquisadores, há muitas sugestões úteis. As estratégias precisariam ser pesquisadas na realidade de cada região.

\section{Geraldina Porto Witter PUC-Campinas}

